\title{
Articles
}

\section{Microwave-Assisted Synthesis of 3-Styrylchromones in Alkaline Ionic Liquid}

\author{
Kiran F. Shelke, Suryakant B. Sapkal, Nana V. Shitole, Bapurao B. Shingate, and Murtidhar S. Shingare \\ Organic Research Laboratory, Department of Chemistry, Dr. Babasaheb. Ambedkar Marathwada Lniversity,

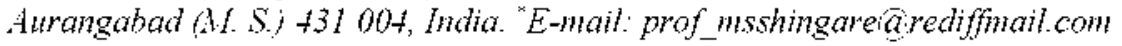 \\ Received Jine 15, 2009, Accepted July 10,2009
}

\begin{abstract}
A simple, highly efficient and environmentally benign method for the synthesis of 3-styrylchromones from 3-fonmylchromones and 4-nitrophenylacetic acid/4-nitrotolune in the presence of catalytic amount of basic ionic liquid 1-butyl-3-methylinidazolium hydroxide [(bmim)OH] carried out under the influence of microwave irradiation. This method gives remarkable advantages such as, short reaction times, simple work-up procedure and moderate to good yields. The ionic liquid was successfully reused for four cycles without significant loss of activity.
\end{abstract}

Key Words: 3-Stỵ rỵlchromone. 3-Formỵ lchromone. [Bmim]OH. Microwave irradiation

\section{Introduction}

Styrylchromones constitute a small but significant group of oxygenated heterocyclic compounds which have shown marked biological activities. ${ }^{1-4}$ Synthetic 2-styrylchromone derivatives exhibit potent cytotoxic. anti-allergic. anti-viral. and anti-cancer activity. Hormathamnione is exceptionally cytotoxic to P388 lymphocytic leukemia and HL-60 promyelocytic leukemia cell lines in vitro and appears to be a selective inlubitor of RNA synthesis ${ }^{\text {fa }}$ and 6-Desmethosyhormothamuione showed cytotoxicity to $9 \mathrm{~KB}$ cell lines. ${ }^{6 \mathrm{~b}}$ Despite the relationship of 3-sty rylchromones with the well-studied 2-styrylchromones very little is known about their biological activities: only anti-fungal and $a n t i$-bacterial activities have been reported.

Due to great importance. many synthetic strategies have been employed for the syththesis of 3-styrylchromone. In 2002. Shingare and coworkers reported the condensation of 3-formylchromones with 2,4-dinitrotoluene in the presence pyridine. A modification of this method ${ }^{8}$ which consists of the condensation of 3-formylchromones with 4-nitrophenylacetic acid followed by decarboxylation reaction, allowed the synthesis of new 3-styry lchromone derivatives. The synthetic method for 3-sty y lchromones involves the Wittig reaction of 3 -formylchromones with benzylic yields ${ }^{9}$ and gives an isomeric mixture of $(E)$ and $(Z) 3$-styrylchromones. The obtained isomers have been separated by thin layer chromatography. Also. Samat $e t a l .{ }^{16}$ reported the stynthesis of novel 3-styrylchromones which can also be regarded as 3-sty y lflavones. These compounds have been obtained from the reaction of 1-(2-hydroxyphenyl)-3-phenylpropan-1.3-diones and phenyl acetaldehydes under a mild acid-catalyzed condition. These methods have not been entirely satisfactory, owing to such drawbacks as low yields, long reaction time. expensive and toxic cataly sts.

Chromones and their derivatives of different oxidation level are well known naturally occurring oxygen-containing hetero- cyclic compounds which perform important biological functions in nature. It is known that certain natural and synthetic derivatives possess important biological activities ${ }^{l-1 j 3}$ such as anti-tumor, anti-hepatotoxic. anti-oxidant. anti-inflammatory. anti-spasmolytic. oestrogenic and anti-bacterial.

In recent years. application of ionic liquids in organic synthesis have attracted considerable attention due to their special properties such as good solvating capability. wide liquid range. negligible vapor pressure easy recycling. high thermal stability and rate enhancers. ${ }^{1+16}$ Nowadays. much attention has been focused on organic reactions catalyzed by ionic liquids. ${ }^{1 ;-19}$ Particularly. imidazolium ionic liquids have been successfully used in many organic transformations

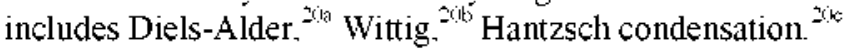

The science of green chenistry is developed to meet the increasing demand of environmentally benign chemical processes. The application of microwaves (MWs). as an efficient heating source for organic reactions and it has been reported in the literature. ${ }^{21}$ The main advantage of microwave assisted organic synthesis is the shorter reaction time using only snall amount of energy. ${ }^{21}$ Many microwave-assisted transformations offer additional convenience in the field of organic sy nthesis because of simple experimental procedure and high yields.

\section{Experimental}

Melting points were obtained on a melting point apparatus with capillary tubes and are uncorrected. IR spectra were recorded on Perkin-Elmer FTIR Spectrophotometer in $\mathrm{KBr}$ disc. ${ }^{\mathrm{H}} \mathrm{H}$ NMR spectra were recorded on Varian $300 \mathrm{MHz}$ spectrophotometer in $\mathrm{CDCl}_{3}$ as a solvent and TMS as an internal standard. Microwave irradiation was carried out in a microwave oven (BPL, 800T, $2450 \mathrm{MHz}$ ) with power output of $800 \mathrm{~W}$.

Synthesis of substituted 3-styrylchromone $3(a-j)$. A mixture of substituted 3 -formylchromone (1 mmol). 4-nitrophenyl- 
acetic acid/4-nitrotolune (1 mmol). [bmim] $\mathrm{OH}$ ( $5 \mathrm{~mol} \%$ ) were taken in a beaker $(50 \mathrm{~mL})$. The reaction mixture was mixed properly with the help of glass rod and irradiated (180 Watt) for a period of $5 \mathrm{sec}$ at a time. The progress of reaction was monitored by TLC. After completion of reaction, the reaction content cooled to room temperature. The product was extracted with diethyl ether $(2 \times 20 \mathrm{~mL})$ and the insoluble ionic liquid [bmim] $\mathrm{OH}$ directly recycled in subsequent runs. The organic layer was washed by brine $(2 \times 10 \mathrm{~mL})$. dried over anhydrous $\mathrm{NaSO}_{4}$ and solvent removed on rotary evaporator under reduced pressure. The crude solid compounds were crystallized by acetic acid to afford the desired products 3 (a-i). All the

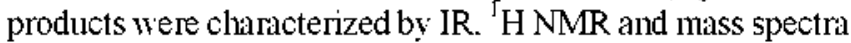
and by comparison of their phy sical characteristics with those of the authentic compounds

Spectral data of principal compounds. Compound (3a): ${ }^{\mathrm{H}} \mathrm{H}$ NMR (CDCl $3.300 \mathrm{MHz}$. òppm): 2.25 (s. $3 \mathrm{H}), 6.70$ (s. IH). $7.60(\mathrm{~s}, 1 \mathrm{H}) .7 .23$ (s. $1 \mathrm{H}), 7.10$ (d. $1 \mathrm{H} . J=12 \mathrm{~Hz}), 6.80$ (d. $1 \mathrm{H}$. $J=12 \mathrm{~Hz}$ ). 7.50 (d. $2 \mathrm{H}, J=8.1 \mathrm{~Hz}$ ). 8.20 (d. $2 \mathrm{H} . J=8.1 \mathrm{~Hz}$ ). Compound (3b): ${ }^{1} \mathrm{H} \mathrm{NMR}\left(\mathrm{CDCl}_{3}, 300 \mathrm{MHz}\right.$. òppm): 2.70 (s, $6 \mathrm{H}) .6 .90(\mathrm{~s} .1 \mathrm{H}) .7 .26$ (s. 1H). 7.21 (s, lH). 7.10 (d. $1 \mathrm{H} . J=$ $12 \mathrm{~Hz}) .6 .80(\mathrm{~d} . \mathrm{H}, J=12 \mathrm{~Hz}) .7 .50(\mathrm{~d} .2 \mathrm{H}, J=8.1 \mathrm{~Hz}) .8 .20$ (d. $2 \mathrm{H} . J=8.1 \mathrm{~Hz}$ ) Compound (3d): ${ }^{1} \mathrm{H}$ NMR $\left(\mathrm{CDCl}_{3}, 300\right.$ MHz, oppm): 6.79 (d. $1 \mathrm{H}, J=8 \mathrm{~Hz}$ ). 7.40 (d. $1 \mathrm{H} . J=8 \mathrm{~Hz}$ ). $7.70(\mathrm{~s}, 1 \mathrm{H}) .7 .21$ (s. $1 \mathrm{H}), 7.10$ (d. $1 \mathrm{H} . J=12 \mathrm{~Hz}), 6.80(\mathrm{~d} .1 \mathrm{H}$. $J=12 \mathrm{~Hz}$ ). 7.50 (d. $2 \mathrm{H}, J=8.1 \mathrm{~Hz}) .8 .20$ (d. $2 \mathrm{H} . J=8.1 \mathrm{~Hz})$ Compound (3e): ${ }^{1} \mathrm{H}$ NMR $\left(\mathrm{CDCl}_{3}, 300 \mathrm{MHz}\right.$, ôppm): 6.92 (s. 1H). $7.70(\mathrm{~s} .1 \mathrm{H}) .7 .26(\mathrm{~s}, 1 \mathrm{H}), 7.10$ (d. $1 \mathrm{H} . J=12 \mathrm{~Hz}) .6 .80$ (d. $1 \mathrm{H}, J=12 \mathrm{~Hz}$ ). 7.50 (d. $2 \mathrm{H} . J=8.1 \mathrm{~Hz}$ ). 8.20 (d. $2 \mathrm{H} . J=$ $8.1 \mathrm{~Hz}$ ) Compound (3f): ${ }^{1} \mathrm{H}$ NMR (CDCl $3.300 \mathrm{MHz}$. oppm); 2.28 (s. $3 \mathrm{H}$ ). 6.80 (s. IH). 6.90 (d. $1 \mathrm{H} . J=8 \mathrm{~Hz}) .7 .80$ (d. $1 \mathrm{H}$, $J=8 \mathrm{~Hz}) .7 .20(\mathrm{~s}, 1 \mathrm{H}) .7 .10(\mathrm{~d} .1 \mathrm{H} . J=12 \mathrm{~Hz}), 6.80(\mathrm{~d} .1 \mathrm{H}$. $J=12 \mathrm{~Hz}), 7.50(\mathrm{~d}, 2 \mathrm{H}, J=8.1 \mathrm{~Hz}) .8 .20(\mathrm{~d} .2 \mathrm{H} . J=8.1 \mathrm{~Hz})$ Compound (3h): ${ }^{1} \mathrm{H}$ NMR $\left(\mathrm{CDCl}_{3}, 300 \mathrm{MHz}\right.$. òppm): 2.30 (s. $6 \mathrm{H}) .6 .68(\mathrm{~s} .1 \mathrm{H}) .7 .40$ (s. $1 \mathrm{H}) .7 .21(\mathrm{~s}, 1 \mathrm{H}) .7 .10$ (d. $1 \mathrm{H} . J=$ $12 \mathrm{~Hz}$ ). 6.80 (d. $1 \mathrm{H} . J=12 \mathrm{~Hz}$ ). 7.50 (d. $2 \mathrm{H} . J=8.1 \mathrm{~Hz}$ ). 8.20 (d. $2 \mathrm{H} . J=8.1 \mathrm{~Hz}$ ) Compound (3j): ${ }^{\mathrm{H}} \mathrm{H}$ NMR $\left(\mathrm{CDCl}_{3} .300\right.$ MHz, òppm): 2.27 (s. 3H). 6.83 (d. 1H. $J=8 \mathrm{~Hz}$ ). 7.31 (d. $1 \mathrm{H}$. $J=8 \mathrm{~Hz}$ ). 7.60 (s. lH) 7.20 (s. IH). 7.10 (d. IH. $J=12 \mathrm{~Hz}$ ). 6.80 (d. $1 \mathrm{H}, J=12 \mathrm{~Hz}) .7 .50(\mathrm{~d}, 2 \mathrm{H}, J=8.1 \mathrm{~Hz}), 8.20$ (d. $2 \mathrm{H}$, $s s=8.1 \mathrm{~Hz}$.

\section{Results and Discussion}

In continuation of our research interest in microwave-assisted<smiles>Cn1cc[n+](C=O)c1</smiles>

Figure 1. 1-Butyl-3-methylinidazolium hydroxide [(bmin $) \mathrm{OH}]$

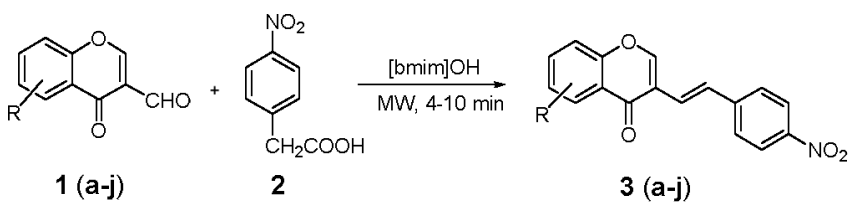

Scheme 1

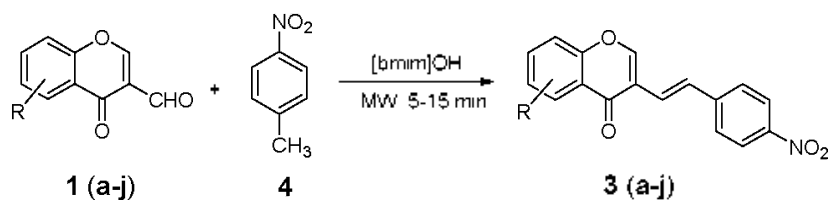

Scheme 2

Table 1. Synthesis of 3-styrylchromones in the presence of [bmim] OH under microwave irradiation."

Entry

"All the products were characterized by IR. ${ }^{1} \mathrm{H}$ NMR and mass spectra and by comparison of their physical characteristics with those of the authentic compounds; "Isolated vield. 
Table 2. Recycling of [bmim] $\mathrm{OH}$ for the synthesis of 3-(4-nitrostyryl)-6-chloro-th-chromen-4-one $3 \mathrm{c}^{4}$

\begin{tabular}{ccc}
\hline Entry & Cycle $^{b}$ & Yield $(\%)^{c}$ \\
\hline 1 & Fresh & 65 \\
2 & $1^{\text {st }}$ & 62 \\
3 & $2^{\text {nd }}$ & 61 \\
4 & $3^{\text {sd }}$ & 59 \\
5 & $4^{\text {d) }}$ & 59 \\
\hline
\end{tabular}

"Reaction condition: $1 \mathrm{a}(\mathrm{lmmol}), 2$ ( $1 \mathrm{mmol})$ and $[\mathrm{bmim}] \mathrm{OH}\left(5 \mathrm{~mol} \mathrm{l}^{\circ} \mathrm{o}\right)$ under microwace irradiation: "Reaction time-5 min: 'Isolated yield.

synthesis ${ }^{20}$ and the development of novel sy'nthetic methodology. ${ }^{23}$ herein. we would like to report a simple, efficient and rapid method for the synthesis of 3-sty rylchromone (Scheme 1 and 2).

In order to find out the optimum reaction conditions. the reaction of 6-chloro-t-oxo- $+H$-chromene-3-carbaldehy'de 1c and 4-nitrophenylacetic acid 2 under the influence of microwave irradiation has been selected as model to investigate the effect of different amount of [bmim] $\mathrm{OH}$ on the yield. The best result was obtained by carrying out the reaction with $1: 1 \mathrm{~mol}$ ratios of 6 -chloro-4-oxo- $H H$-chromene-3-carbaldehyde : 4-nitropheny lacetic acid and $5 \mathrm{~mol} \%$ of [bmim] OH (Figure 1) under microwave irradiation. Under this condition. 3-(4-nitrosty ryl)6 -chloro-t $H$-cluromene-4-one $3 \mathrm{c}$ was obtained $65 \%$ yield after 5 min (Table 1. entry $3 \mathrm{c}$ ). The same reaction was carried out in the absence of [bmim] $\mathrm{OH}$ under the same conditions. which resulted in no product formation within $30 \mathrm{~min}$. This result indicates that [bmim] $\mathrm{OH}$ exhibit a high catalytic activity towards this organic transformation.

To evaluate the effect of MW for the model reaction (Table 1. entry 3c). we first examined the reaction without MW at $100{ }^{\circ} \mathrm{C}$. We found low yield $(35 \%)$ with prolonged reaction time (110 min) and using MW amazingly we found excellent yield $(65 \%)$ with short reaction time (5 min). Therefore, we chose this method to perform the synthesis of all derivatives of 3-styrylchromone under MW irradiation.

The results of this study are summarized in Table 1. With the optimized reaction condition in hand we have synthesized various 3-styrylchromone derivatives from substituted 3-formylchromone in the presence of $[\mathrm{bmim}] \mathrm{OH}$ under influence of microwave irradiation. The condensation of 3 -formylchromones with 4-nitropheny lacetic acids followed by decarboxy'lation reaction allowed the synthesis of new 3-sty ry lchromone derivatives and gave only the $(E)$ isomer. The successful synthesis of 3-styrylchromone derivatives in shorter reaction times ( 5 - $15 \mathrm{~min}$ ) with moderate to good yields. It is found that condensation of 3-formylchromones with 4-nitrophenyl acetic acid (Scheme 1) required less time as comparied to t-ritrotolune (Scheme 2). Moreover. yields with 4-nitrophenyl acetic acid $(54-70 \%)$ are found to be good as compared to 4-nitrotolune $(30-53 \%)$. This methodology avoids the use of strong base. hazardous solvents and requires only catalytic amount of the basic ionic liquid to promote the reaction.

In view of economical and environmental friendly methodologies. recovery and reuse of the ionic liquid is highly preferable. As indicated in Table 2 (entry $3 \mathrm{c}$ ), recycled ionic liquid shows no loss of efficiency with regard to reaction time and yield after four successive runs.

\section{Conclusion}

In conclusion. we have emphasized a new and effective methodology for the synthesis of 3-styrylchromone derivatives. The notable merits of the present methods are short reaction times. simple work-up procedure and moderate to good yield of products. Moreover. the [bmim] $\mathrm{OH}$ was successfully reused for four cycles without significant loss of activity. Thus a rapid comvenient and environmentally benign method for the synthesis of compounds of type $3(\mathbf{a}-\mathbf{j})$ have been achieved. To the best of our knowledge this is first report on synthesis of 3-sty ñlchromones derivatives in basic ionic liquid.

Acknowledgments. The authors are thankful to the Head. Department of Chemistry. Dr. Babasaheb Ambedkar Marathwada University. Aurangabad-431 004. MS. India for providing the laboratory facility.

\section{Refeiences}

1. Desideri, N.; Conti, C.; Mastropaolo, F. Antiviral Chem. Chemother $2000,11,373$.

2. Peixoto, F; A. Barros, I. R. N. A.; Silva, A. M. S. J. Biochem. Mol. Toxicol. 2002, 16.220.

3. Femandes, E.; Carvalho, M.; Carvalho, F.; Silva, A. M. S: Santos, C. M. M.; Pinto, D. C. G. A.; Cáaleiro, J. A. S.; Bástos, M. L. Arch. Toxicol 2003, 77, 500 .

4. Filipe, P.; Silva, A. M. S.; Morlière, P.; Brito, C. M.; Patterson, L. K.: Hug, G. L.: Silva, J. N.: Cávaleiro, J. A. S.: Mazière, J.-C.; Freitas, J. P.; Santus, R. Biochent. Phamacol 2004, 67, 2207.

5. (a) Doria, G.: Romero, C.: Forgione, A.; Sberze, P.; Tibolla, N.; Como, M. L.: Cruzzola, G.: Cadelli, G. Eur. J. Wed. Chem. 1979, 14, 347. (b) Brion, J. D.; Le Baut, G.; Zammattio, F; Pierre, A; Atassi, G.: Belachmi, L. Eur. Pat. Appl. 1991, EP 454, 587; Chent Abstr: 1992, 116, 106092K.

6. (a) Gerwick, W. H.; Lopez, A.: Van Duyne, G. D.: Clardy, T.; Ortiz, W. Bàz, A. Tetrahedron Lett. 1986, 27, 1979 (b) Gerwick, W. H. J. Nat. Prod. 1989, 52, 252

7. Sonawane, S. A.: Chavan, V. P.; Karale, B. K.: Shingare, M. S. Ind. J. Heterocviclic Chem. 2002, 12,65

8. (a) Karale, B. K.; Gill, C. H.; Shingare, M. S. Ind. J. Heterocycl. Chem. 2003, 12, 267. (b) Silva, V. L. M.: Silva, A. M. S.: Pinto, D. C. G. A.; Cavaleiro, T. A. S. Aweiro. 2003, $\mathrm{PO}_{102,148 .}$

9 Sandulache, A.; Silva, A. M. S.; Pinto, D. C. G. A.; Almeida, L. M. P. M: Cavaleiro, J. A. S. Vew J. Chent. 2003, 27, 1592.

10. Lokshin, V;: Heynderickx, A.: Samat, A.; Pèpe, G.: Guglielmetti, R. Tetrahedron Lett. 1999, 40,6761 .

11. Atassi, G.; Briet, P; Berthelon, J. P.; Collonges, F. J. Med. Chem. Chim. Ther: 1985, 20, 393.

12. Middleton, Tr, E.; Kandaswami, C. The Flovonoids Advonces in Research Since 1986; Harborne, J. B., Ed.; Chapman: Hall, London, 1994: p 619.

13. Harbome, J. B.; Williams, C. A. Ptytochemismy 2000, 55, 481

14. Thomas, W. Chem. Rev' 1999,99, 2071.

15. Sheldon, R. Chem. Commun. $2001,2399$.

16. Zhao, D: Wu, M: Kou, Y.; Min, K. Catal. Todov 2002, $2654,1$.

17. Peng. T.; Deng, Y. Tetrahedron Lett. 2001, 42, 403.

18. Shen, Z. L.; Zhou, W. T; Liu, Y. T, Ji, S. J.; Loh, T. P. Green Chem. 2008, 10, 283.

19. Gong, $\mathrm{K} ; \mathrm{He}, \mathrm{Z} . \mathrm{W} ; \mathrm{Xu}, \mathrm{Y} ;$ Fang, D.; Liu, Z.-L. Montotsh. 
Chem. 2008, 139,913

20. (a) Fischer, T.: Sethi, A.; Welton, T.; Woolf, T. Tetrahedron Lett. 1999, 40,793 . (b) Le Boulaire, V. R. Chem. Commm. 2000. 2195. (c) Ji, S. J.; Jiang, Z. Q.: Lu, J.; Loh, T. P Synlett 2004, 5, 831 .

21. Kahveci, B.; Ozil, M.: Serdar, M. Heteroatom Chem 2008, 19, 38.

22. (a) Karale, B. K.; Chavan, V. P.; Mane, A. S.; Hangarge, R. V.; Gill, C. H.; Shingare, M. S. Simth. Comm. 2002, 32, 497. (b) Shindalkar, S. S.: Madje, B. R.; Shingare, M. S. Mendeleev Commm 2007, 17, 43. (c) Sapkal, S. B.; Shelke, K. F.: Shingate, B. B.: Shingare, M. S. Tetrahedron Lett. $2009,50,1754$.
23. (a) Pawar, S. S.: Dekhane, D. V.; Shingare, M. S.; Thore, S. N. Tetrahedron Lett 2008, $\$ 9,4252$ (b) Sadaphal, S. A.; Shelke, K. F.; Sonar, S. S.: Shingare, M. S. Central Ewo. J. Chem. 2008, 6 , 622. (c) Diwakar, S. D.; Bhagwat, S. S.; Shingare, M. S.; Gill, C. H. Bioorg. Med. Chent Lett. 2008, 18, 4678. (d) Shelke, K. F.; Sapkal, S. B.: Shingare, M. S. Chie. Chem. Letr. 2009, 20, 283. (e) Shelke, K. F.; Sapkal, S. B.; Sonar, S. S.: Madje, B. R.; Shingate, B. B.; Shingare, M. S Bull. Korean Chent. Soc. 2009, 30, 1057. (f) Shelke, K. F.; Madje, B. R.; Saphal, S. B.; Shingate, B. B.: Shingare, M. S. Gneen Chem. Lett. Rev. 2009, 2, 3. (e) Shelke, K. F.: Sapkal, S. B.; Kategankar, A. H.: Shingate, B. B.: Shingare, M. S. S. Affr. J. Chem. 2009, 62, 109. 